\title{
CONSTRAINTS BEING PERCEIVED BY SHEEP REARERS IN ARID AND SEMIARID REGION OF RAJASTHAN
}

\author{
M. L. CHOUdHARY, VIJAY KUMAR, S. C. GOSWAMI \\ V. SINGH* AND V. KUMAR \\ Department of Livestock Production Management \\ College of Veterinary and Animal Science \\ Rajasthan University of Veterinary and Animal Sciences \\ Bikaner -334 001, Rajasthan, India
}

The data were collected from 120 sheep rearers selected from 8 villages of two tehsils of Bikaner district. The information was collected from respondents on breeding practices of sheep by an interview schedule. On the basis of Rank based quotient (RBQ) value the main constraints identified were lack of grazing area and non-availability of green fodder with the RBQ values of 64.08 and 62.50 respectively. Lack of veterinary services was the third most serious constraint perceived by respondents obtaining $R B Q$ value at $58.42 \%$. Similarly, other constraints identified by respondents were ranked on the basis of the RBQ values.

Key words: Arid and semi arid region, Constraints, Respondents, Sheep rearers

The sheep in India are mostly reared by the landless laborers and marginal farmers, who are considered as the socially and economically disadvantaged sections in the rural society. It provides gainful employment and income to the weaker sections especially to the rural poor. They contribute about 4.5 million tons of meat and 43.1 million $\mathrm{kg}$ of wool in India (BAHS, 2017).

In the last decade, small ruminants in developing countries were less productive than those in developed countries (Winrock International, 1983). However, the total product from small ruminants increased in developing countries because their numbers increased. This indicates that if developing countries could increase herd productivity, they could increase production. However, to increase production in developing countries, existing constraints must be surmounted. The objective of present study

\footnotetext{
* Corresponding Author
} 
was to identify the constraints being perceived by the respondents in adoption of improved sheep management practices in arid and semi arid region of Rajasthan.

\section{MATERIALS AND METHODS}

The study was conducted in Bikaner district of Rajasthan. The data were collected from randomly selected 120 sheep rearers, from 8 villages of two tehsils of Bikaner district. Total 120 sheep rearers were categorized in to three categories on the basis of flock size:

i) Small holding (1-20 sheep)

ii) Medium holding (21-40 sheep)

iii) Large holding (Above 40 sheep )

The information was collected on various management practices adopted by sheep rearers through an interview schedule.

\section{Analysis of data and statistical test} applied: The data were analyzed by using collected information, several statistical tools and methods. The following statistical treatments were used for interpretation of data:

Rank based quotient (RBQ): On the basis of ranks provided by the farmers, rank based quotient (RBQ) for each constraint was calculated at village level on basis of the formula (Sabarathnarn and Venila, 1996).

$$
R B Q=\sum_{i=1}^{n} \frac{f i(n+1-i)}{N n} \times 100
$$

Where, $F_{i}=$ the frequency of farmers for the $i^{\text {th }}$ rank of the constraint

$\mathrm{N}=$ the numbers of farmers

$\mathrm{n}=$ the number of ranks
Similarly, the RBQ values at tehsil level and the pooled RBQ values of the two tehsils were calculated using weighted average of village and tehsil level values.

\section{RESULTS}

Constraints being perceived by the respondents: On Rank-based quotient (RBQ) values, the researcher easily identified the most serious constraint at tehsil level. The constraints having higher RBQ value may be indicated as more serious constraints. Pooled and tehsil wise RBQ value for two tehsil are presented in Table 1.

The results indicated that the lack of grazing area was most serious constraints faced by sheep rearers on pooled RBQ basis. The RBQ value of this constraint was 64.08. The constraint of lack of grazing area was ranked second in Bikaner tehsil and first in Lunkarnsar tehsil with RBQ value 66.50 and 61.67 respectively. Second most serious constraint was non-availability of green fodder with a RBQ value of 62.50 on pooled RBQ basis. Based on distribution of RBQ values, this constraint was ranked first in Bikaner tehsil and second in Lunkarnsar tehsil (RBQ value 67.33 and 57.67 respectively). Lack of veterinary services was the third most serious constraint in the area surveyed and it had the RBQ value of 58.42. This constraint ranked third in Bikaner tehsil and fourth in Lunkarnsar tehsil. (RBQ value 59.67 and 57.17 respectively). 
Table 1. Pooled and Tehsil wise RBQ values of different constraints

\begin{tabular}{|c|c|c|c|c|c|c|c|}
\hline \multirow[t]{3}{*}{ Constraints } & \multirow{3}{*}{$\begin{array}{l}\text { Constraint } \\
\text { code }\end{array}$} & \multirow[t]{3}{*}{ Values } & \multirow[t]{3}{*}{ Rank } & \multicolumn{4}{|c|}{ Tehsil } \\
\hline & & & & \multicolumn{2}{|l|}{ Bikaner } & \multicolumn{2}{|c|}{ Lunkarnsar } \\
\hline & & & & Constraints & \multicolumn{2}{|c|}{ RBQ Constraints } & \multirow{2}{*}{$\begin{array}{l}\text { RBQ } \\
57.67\end{array}$} \\
\hline $\begin{array}{l}\text { Non-availability of } \\
\text { green fodder }\end{array}$ & 1 & 62.50 & 2 & 1 & 67.33 & 2 & \\
\hline Lack of grazing area & 2 & 64.08 & 1 & 2 & 66.50 & 1 & 61.67 \\
\hline $\begin{array}{l}\text { Lack of veterinary } \\
\text { services }\end{array}$ & 3 & 58.42 & 3 & 3 & 59.67 & 4 & 57.17 \\
\hline Lack of credit facility & 4 & 57.50 & 4 & 4 & 57.50 & 3 & 57.50 \\
\hline breeding ram & 5 & 53.67 & 5 & 5 & 53.00 & 6 & 54.33 \\
\hline $\begin{array}{l}\text { Illiteracy } \\
\text { Inadequate price for the }\end{array}$ & 6 & 52.00 & 7 & 6 & 50.67 & 7 & 53.33 \\
\hline animals & 7 & 53.17 & 6 & 7 & 50.17 & 5 & 56.17 \\
\hline $\begin{array}{l}\text { High cost of } \\
\text { concentrate } \\
\text { feeding }\end{array}$ & 8 & 48.92 & 9 & 8 & 49.83 & 10 & 48.00 \\
\hline $\begin{array}{l}\text { Lack of knowledge } \\
\text { about scientific } \\
\text { sheep rearing }\end{array}$ & 9 & 51.08 & 8 & 9 & 49.17 & 8 & 53.00 \\
\hline $\begin{array}{l}\text { Higher lamb } \\
\text { mortality }\end{array}$ & 10 & 48.67 & 10 & 10 & 46.17 & 9 & 51.17 \\
\hline
\end{tabular}

Lack of credit facility was the fourth serious constraint identified (Pooled RBQ value, 57.50) in the study area. Based on tehsil wise RBQ values, the constraint was ranked fourth in Bikaner tehsil and third Lunkarnsar with RBQ value 57.50 and 57.50 respectively.

Lack of improved breeding ram was the fifth rank constraint in the surveyed area. Based on tehsil wise RBQ values the constraint was ranked fifth in Bikaner tehsil and sixth in Lunkarnsar tehsil with RBQ value 53.00 and 54.33 respectively.

Inadequate price for the animals ranked sixth with pooled RBQ value 53.17. This constraint ranked fifth in Lunkarnsar and seventh in Bikaner with RBQ value 56.17 and 50.17 respectively.

The pooled RBQ values for the constraint 
Illiteracy was obtained at 52.00 and ranked at seventh. This constraint ranked seventh in Lunkarnsar while, sixth in Bikaner tehsil.

For lack of knowledge of scientific sheep rearing, pooled RBQ value was 51.08 and ranked at eighth. On the basis of tehsil wise RBQ values, ranked as eighth in Lunkarnsar while, ninth in Bikaner with RBQ value 53.00 and 49.17 respectively.

High cost of concentrate feeding ranked ninth with pooled RBQ value 48.92. This constraint ranked eighth in Bikaner while, tenth in Lunkarnsar with RBQ value 49.83 and 48.00 respectively.

\section{DISCUSSION}

Constraints being perceived by sheep rearers in arid and semi-arid region of Rajasthan. The major constraints were nonavailability of green fodder, lack of grazing area, lack of veterinary services, lack of credit facility, lack of improved breeding ram, inadequate price for the animals, illiteracy and poor knowledge of scientific sheep rearing. These findings are almost similar to that recorded by Nitharwal (1999), Kulkarni and Jawahar (2000), Kumar (2003), Mohan and Singh (2004), Meganathan et al. (2004), Senthil and Meganathan (2005), Singh and Chauhan (2006), Porwal et al. (2006), Gurjar and Pathodia (2008), Suresh et al. (2008) but are contradictory with findings of Eswara and Radha (1996), Misra et al. (2000), Kumaravel and Krishnaraj (2007), Swarnkar and Singh (2010).

On the basis of RBQ values lack of grazing area (64.08) was most serious constraint perceived by the farmers followed by nonavailability of green fodder, lack of veterinary services, lack of credit facility and lack of improved breeding ram.

\section{ACKNOWLEDGEMENT}

The authors thankfully acknowledged the financial support and facilities provided by RAJUVAS, Bikaner to carry out the research work.

\section{REFERENCES}

BAHS (Basic Animal Husbandry Statistics), 2017. Govt. of India, Ministry Of Agriculture, Dept. Of Animal Husbandry Dairying \& Fisheries, Krishi Bhavan, New Delhi
Eswara Prasad Y and Radha Y, 1996. Constraints in sheep marketing: perception of marketing of sheep and sheep products. Indian J Agric Market, 10(2): 105 
Gurjar ML and Pathodiya OP, 2008. Constraints perceived by farmers in goat rearing in Mewar region of southern Rajasthan. Indian J Anim Sci, 78 (1): 124-126

Kulkarni VV and Jawahar TP, 2000. Performance of Tellicherry goats under intensive system. International conference on small holder livestock production systems in developing countries, November 24-27 at Thrissur, Kerala, India, pp12

Kumar D, 2003. A study on problems encountered in sheep rearing in Rajasthan. Indian J Small Rumin, 9(1): 43-46

Kumaravel P and Krishnaraj R, 2007. Adoption of improved sheep and goat husbandry practices in Pudukottai district of Tamil Nadu. Indian J Small Rumin, 13(1): 4550

Meganathan N, Pandian ASS, Selvakumar KN and Prabaharan R, 2004. Structural and composition change in small ruminant populations of Tamil Nadu. Indian J Small Rumin, 10(2): 166-168

Misra AK, Rekha MS, Reddy GS and Singh HP, 2000. Sheep and goat farming in rainfed areas: constraints and options for improvement on small holder production systems. International conference on small holder Livestock production systems in developing countries, at Thrissur, Kerala, India, pp37

Mohan B and Singh K, 2004. General constraints and suggestions in relation to goat rearing. $2^{\text {nd }}$ National extension education congress, May 22-24, MPUAT, Udaipur (Rajasthan.)

Nitharwal UK, 1999. Current status and problems of goat management in tribal and non-tribal area of Jaipur district. M. Sc. thesis submitted to RAU, Bikaner

Porwal K, Karim SL, Sisodia SL and Singh VK, 2006. Socio-Economic survey of sheep farmers in western Rajasthan. Indian J Small Rumin, 12(1):74-81

Sabarathnarn VE and Vennila S, 1996. Estimation of technological needs and identification of problems of farmers for formulation of research and extension programmes in Agricultural Entomology. Expl Agric, 32: 87-90

Senthil Kumar G and Meganathan N, 2005. Marketing of sheep/ mutton. Indian J Marketing, 19(3): 52-60

Singh M and Chauhan A, 2006. Constraints faced by dairy owners in adoption of scientific dairy farming practices. Indian J Dairy Sci, 59(1): 49-51

Suresh A, Gupta DC and Mann JS, 2008. Farmers' management practices and 
economics of sheep farming in eastern semi-arid region of Rajasthan. Indian J Small Rumin, 14(2): 236-242

Swarnkar CP and Singh D, 2010. Questionnaire survey on sheep husbandry and worm management practices adopted by farmers in Rajasthan. Indian J Small Rumin, 16(2):199-209

Winrock International, 1983. Sheep and goats in developing countries. A World Bank Technical Paper. The World Bank, Washington D.C. 